\title{
FARMERS' BEHAVIORAL INTENTION TO ADOPT PEER-TO-PEER LENDING USING UTAUT2 APPROACH
}

\author{
Hera Laxmi Devi Septiani* ${ }^{* 1}$, Ujang Sumarwan ${ }^{* *}$, Lilik Noor Yuliati**), and Kirbrandoko $\left.{ }^{* * *}\right)$ \\ *) School of Business, IPB University \\ Jl. Pajajaran, Bogor 16151, Indonesia \\ ${ }^{* *}$ Department of Family and Consumer Sciences, Faculty of Human Ecology, IPB University \\ Jl. Lingkar Akademik, Dramaga, Bogor, Indonesia 16680 \\ $\left.{ }^{* * *}\right)$ Ibn Khaldun Bogor University \\ Jl. Sholeh Iskandar, Bogor, Indonesia 16162
}

\begin{abstract}
The limited access of smallholder farmers to funding sources is one of the main challenges facing Indonesia agriculture sector. In order to address this constraint some Fintech entities have initiated peer-to-peer (P2P) lending for funding the farming. Different from formal financial institution, farming funding P2P lending facilitates farmers by not requiring any collateral and applying profit sharing scheme instead of interest, which is in favor of smallholder farmers condition. Irrespective of the benefits, the adoption rate of farming funding P2P lending by farmers is still relatively low. Based on this background, the objective of this study is to investigate the factors influencing the behavioral intention of farmers to adopt farming funding P2P lending. This study uses variables of UTAUT2 and Schwartz Theory of Basic Values. The respondents of this research are 530 farmers in West Java, Indonesia who have and have not participated in farming funding P2P lending. The respondents are selected using purposive sampling method. The population of adopter farmers are the members of farming funding P2P lending providers Crowde and TaniFund. Whereas the non-adopter farmers are selected based on representation of various farming commodities. The data is analyzed using SEM, demonstrating the results that there are five variables showing significant correlation with behavioral intention to adopt P2P lending, which are performance expectancy, hedonic motivation, price value, habit and values.
\end{abstract}

Keywords: consumer behavior, peer-to-peer lending, technology adoption, UTAUT2, valuess

\begin{abstract}
Abstrak: Terbatasnya akses petani kecil terhadap sumber-sumber pendanaan merupakan salah satu masalah terbesar yang dihadapi sektor pertanian Indonesia. Untuk mengatasi permasalahan ini beberapa lembaga Fintech menyediakan layanan peer-to-peer (P2P) lending untuk pembiayaan pertanian. Meskipun P2P lending ini memberikan manfaat bagi petani antara lain karena tidak memerlukan agunan dan menerapkan sistem bagi hasil, tingkat adopsinya sejauh ini masih relatif rendah. Berdasarkan latar belakang tersebut penelitian ini bertujuan untuk menginvestigasi faktor-faktor apa saja yang mempengaruhi niat berperilaku petani dalam mengadopsi P2P lending pembiayaan pertanian. Penelitian ini menggunakan variabel-variabel dari teori UTAUT2 dan Teori Nilai-Nilai Dasar Schwartz. Responden dari penelitian ini adalah 530 petani di wilayah Jawa Barat yang telah dan belum menggunakan P2P lending pembiayaan pertanian. Responden dipilih dengan menggunakan metode purposive sampling. Populasi petani yang telah menggunakan P2P lending pembiayaan pertanian adalah petani anggota Crowde dan TaniFund, sedangkan petani yang belum menggunakan P2P lending pembiayaan pertanian dipilih berdasarkan jenis komoditi pertanian yang dihasilkan. Data dianalisis dengan menggunakan SEM, menunjukkan hasil bahwa terdapat lima variabel yang memiliki hubungan signifikan dengan niat berperilaku mengadopsi P2P lending pembiayaan pertanian, yaitu ekspektasi terhadap kinerja, motivasi hedonis, nilai harga, kebiasaan dan nilai.
\end{abstract}

Kata kunci: perilaku konsumen, peer-to-peer lending, adopsi teknologi, UTAUT2, nilainilai

${ }^{1}$ Corresponding author:

Email: deardevi@gmail.com 


\section{INTRODUCTION}

The accessibility to the sources of capital or funding is very limited, particularly for the smallholder farmers which is the biggest community of the society (Hermawan and Adrianyta, 2013; Mulyaqin et al. 2016; Nurmanaf, 2007). The difficulty associated with accessing finance is due to constraints in land ownership, which are usually needed as collateral, is one of the difficulties associated with accessing finance by agricultural workers (Pattern and Rosengard, 1991; Johnston and Murdoch, 2008; Anggraeni, 2009; Ayyagari et al. 2010).

The banking institution normally shows no interest to finance farming sector because it is considered high risk, due to natural disturbance such as flood and drought, pests and plant diseases, and output price fluctuation. The limited banking financing for farming sector is caused by the mismatched business characteristics in agribusiness sector and banking business (Pratiwi et al. 2019).

Referring to Indiastuti (2005) this situation is caused by some factors; the experience and trauma of banks facing the bad credit, the regulation of Bank of Indonesia which demands banks to be prudent in giving credit, and many banks (particularly big banks) do not have experience in distributing micro credit. Subsequently the informal sources of capital become the alternative options for farmers to get funding (Wineka, 2019).

Peer-to-peer (P2P) lending or crowdfunding is one of the options for farmers to get capital. Crowdfunding is one of the solutions gaining capital from society (Mardhiyyah et al. 2020). P2P lending system allows farmers to apply for loans on platform/sites/marketplaces online, which then investors (individuals) can also choose suitable agricultural projects to be capitalized through electronic system with internet networks.

The concept of personal lending is actually not a new business model, but a traditional way to lend or borrow money only without mediator (Everett, 2010; HerreroLopez, 2009). The factor that makes online peer-topeer lending a new phenomenon is the use of internet in the transaction. Indonesian Financial Service Authority (OJK) regulation no. 77 year 2016 explains that peerto-peer lending is a financial service operation which mediates the lender and the borrower in order to do lending agreement in Indonesian Rupiah directly via electronic system using internet network.

Different from banking institutions, farming funding P2P lending facilitates farmers by not requiring any collateral and applying profit sharing scheme instead of interest which is in favor of smallholder farmers condition. Farming funding P2P lending provider also facilitates the farmers by providing the online marketing channel for selling the crops, which is not provided by formal banking institution (Wineka, 2019). Other benefits provided by the P2P lending provider is the availability of field agents who help the farmers on processing the funding proposal and expert agricultural advisors who give advices to farmers on farming methods. However, irrespective of the benefits of farming funding P2P lending, the farmers who participated is still relatively low. Presumably one of the causes is the low rate of internet adoption among farmers, which is only around $13.4 \%$ of total Indonesian farmers (BPS, 2018). Meanwhile, P2P lending process requires technology of internet connection.

The study on farmers behavior is still scarce. The farmers acceptance towards sharing economy or peerto-peer lending has never been investigated in previous researches. Some studies on technology adoption were conducted in the context of mobile banking (Alalwan, Dwivedi and Rana, 2017), E-Services (Al Imarah et al. 2013), agricultural technology (Banerjee et al. 2016). Hence, this research is expected to contribute to enrich the literature on peer-to-peer lending adoption in agribusiness field.

Considering technology is a major part in $\mathrm{P} 2 \mathrm{P}$ lending, in order to investigate the driving factors of farmers to adopt P2P lending this research adopts variables of The Unified Theory of Acceptance and Use of Technology (UTAUT) 2 (Venkatesh et al. 2012) which studied about acceptance and use of technology in the context of mobile application from consumer's point of view. There are seven variables in this theory, which demonstrated a significant correlation with behavioral intention. The seven variables are performance expectancy, effort expectancy, facilitating conditions, social influence, hedonic motivation, price value, and habit. This study also includes new variable, which is values, adopted from Schwartz Theory of Basic Values. Values are considered relevant to study about farmers behavior considering values are used to 
identify cultural group, society and individual to trace and explain the underlying motivation of an attitude or behavior (Schwartz, 2012). There are ten types of goal or motivation that distinguish values; self-direction, stimulation, hedonism, achievement, power, security, conformity, tradition, benevolence, universalism (Schwartz, 2012).

Considering farming funding P2P lending offers many benefits for the farmers, it is necessary to drive its adoption to allow smallholder farmers get access to capital source. Accordingly, this study is aimed to investigate the factors influencing farmers' behavioral intention to adopt $\mathrm{P} 2 \mathrm{P}$ lending.

\section{METHODS}

This research is a quantitative research using confirmatory approach. The respondents in this research are 530 farmers located in Bandung, Sukabumi and Kuningan, West Java, Indonesia. The data were collected from January 2020 to March 2020.

Samples are selected using purposive sampling method, consists of 159 farmers who have participated in farming funding P2P lending provided by Crowde and TaniFund, which is equal with 60 percent of the total population of farmers who have adopted P2P lending in West Java. The locations of adopter farmers were obtained from the farming funding P2P lending providers Crowde and TaniFund. Crowde and TaniFund are the biggest farming funding $\mathrm{P} 2 \mathrm{P}$ lending providers which are registered and supervised by Indonesian Financial Services Authority (OJK). Whereas the non-adopter 371 farmers are selected based on representation of farming commodities; vegetables, rice and livestock.

This research consists of dependent and independent variables, in which the dependent variable is behavioral intention. Whereas the independent variables are performance expectancy, effort expectancy, facilitating conditions, social influence, hedonic motivation, price value, habit, and values. The summary of variable operationalization can be seen in Table 1 .

This research uses Structural Equation Modelling (SEM) technique for testing the relationship between research variables in the model. The hypotheses are tested with the farmers as the analysis unit. SEM has the capability to investigate and test the hypothesis involving multiple regression analysis among single dependent variable and a group of independent variables (Bentler and Chou, 1987).

As shown in the conceptual framework, there are eight variables adopted from UTAUT2 and Schwartz Theory of Basic Values that hypothetically influence the farmers' behavioral intention to adopt farming funding $\mathrm{P} 2 \mathrm{P}$ lending. Both theories are adopted to formulate the conceptual framework, as can be seen in Figure 1 .

Tabel 1. Variable operationalization

\begin{tabular}{|c|c|c|}
\hline Variable & Definition & Source \\
\hline $\begin{array}{l}\text { Performance } \\
\text { Expectancy (PE) }\end{array}$ & $\begin{array}{l}\text { A level of which one believes that using a system } \\
\text { will help to achieve benefit in work performance }\end{array}$ & $\begin{array}{l}\text { Venkatesh et al. (2012); Botsman and Rogers, } \\
\text { (2010); Kim et al. (2015) }\end{array}$ \\
\hline $\begin{array}{l}\text { Effort Expectancy } \\
\text { (EE) }\end{array}$ & Perception of easiness in using the technology & $\begin{array}{l}\text { Venkatesh et al. (2012); Koufaris \& Hampton- } \\
\text { Sosa (2004); Cao, Zhang, \& Seydel. (2005) }\end{array}$ \\
\hline $\begin{array}{l}\text { Facilitating } \\
\text { Conditions (FC) }\end{array}$ & $\begin{array}{l}\text { Perception of resource availability which helps } \\
\text { farmer easier to adopt technology }\end{array}$ & $\begin{array}{l}\text { Venkatesh et al. (2012); Khalifa and Kathi } \\
\text { (2008); Davis (1989) }\end{array}$ \\
\hline Social Influence (SI) & $\begin{array}{l}\text { A level of which one perceived by surrounding } \\
\text { people that he/she will use new system }\end{array}$ & Venkatesh et al. (2012) \\
\hline $\begin{array}{l}\text { Hedonic Motivation } \\
\text { (HM) }\end{array}$ & $\begin{array}{l}\text { Perception towards enjoyment that will be felt when } \\
\text { using technology }\end{array}$ & $\begin{array}{l}\text { Venkatesh et al. (2012); Van der Heijden, } \\
\text { Verhagen, \& Creemers (2004) }\end{array}$ \\
\hline Price Value (PV) & $\begin{array}{l}\text { Perception towards the amount of benefits compared } \\
\text { to cost }\end{array}$ & $\begin{array}{l}\text { Venkatesh et al. (2012); Chen and Salmanian } \\
\text { (2017); }\end{array}$ \\
\hline Habit $(\mathrm{H})$ & Perception towards automatic Behavior & Venkatesh et al. (2012) \\
\hline Basic Values (V) & Tradition; Achievement; Benevolence; Stimulation & Schwartz (2012) \\
\hline $\begin{array}{l}\text { Behavioral Intention } \\
\text { (BI) }\end{array}$ & Tendency to adopt sharing economy P2P lending & $\begin{array}{l}\text { Venkatesh et al. (2012); Davis (1989); } \\
\text { Fishbein \& Ajzen (1975) }\end{array}$ \\
\hline
\end{tabular}




\section{ADOPTION DRIVERS}

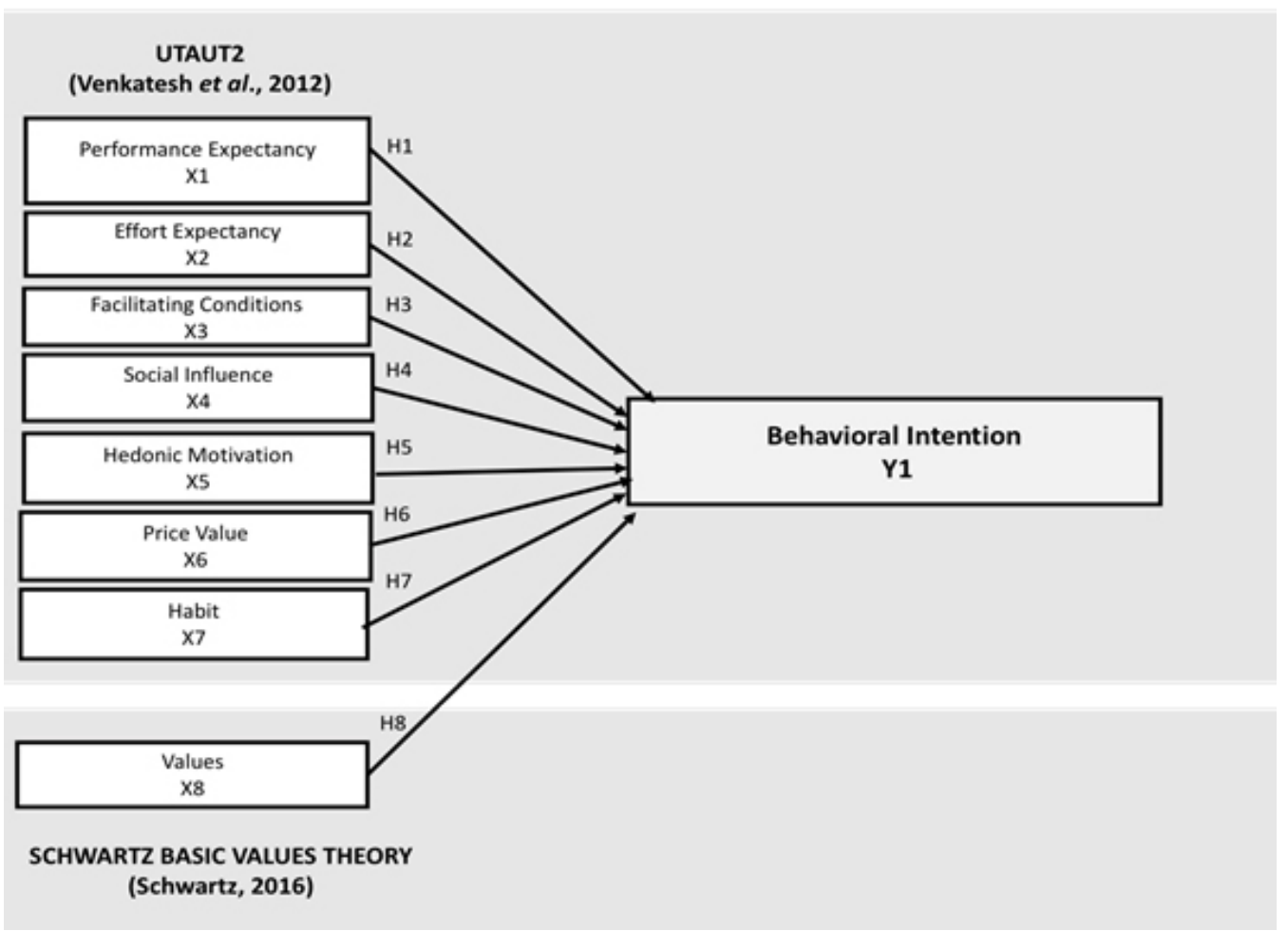

Figure 1. Conceptual framework

\section{Hypotheses}

Based on the above explanation of UTAUT2 and Schwartz Theory of Basic Values, the research hypotheses are concluded below:

H1: Performance expectancy has positive effect on behavioral intention to adopt P2P lending

H2: Effort expectancy has positive effect on behavioral intention to adopt P2P lending

H3: Facilitating conditions have positive effect on behavioral intention to adopt $\mathrm{P} 2 \mathrm{P}$ lending

H4: Social influence has positive effect on behavioral intention to adopt $\mathrm{P} 2 \mathrm{P}$ lending

H5: Hedonic motivation has positive effect on behavioral intention to adopt $\mathrm{P} 2 \mathrm{P}$ lending

H6: Price value has positive effect on behavioral intention to adopt $\mathrm{P} 2 \mathrm{P}$ lending

H7: Habit has positive effect on behavioral intention to adopt $\mathrm{P} 2 \mathrm{P}$ lending

H8: Values has positive effect on behavioral intention to adopt P2P lending

\section{RESULTS}

The respondent characteristics of this study can be seen in Table 2. The average age of the farmers are above 40 years old. The majority religion is Islam. Most farmers are senior high school and elementary school graduate, whereas the number of college-educated farmers are relatively low. Most of farmers have farming experience above 5 years. Referring to Table 3 majority of farmers have no experience borrowing fund offline. Those who have experience with offline lending mostly borrowed not from formal institution.

The findings also show that $42.7 \%$ of farmers borrow from conventional bank and $53.04 \%$ borrow from informal financial entity which is moneylender or loan shark and middleman. The main reason why they choose to borrow from moneylender and middleman is because the requirements are much simpler compared to formal financial institution. The role of financial institution whether it is formal or informal is highly needed by farmers for the purpose of farming production and daily living cost before the crop can be sold. Middleman has various roles which cause the farmers depend on them, not only as capital provider but also due to their important role in forming networking with various parties from the farmers to traders (Megasari, 2017). 
Table 2. Respondent characteristics

\begin{tabular}{|c|c|c|}
\hline Category & $\mathrm{N}$ & $\%$ \\
\hline \multicolumn{3}{|l|}{ Age } \\
\hline$<30$ y.o. & 72 & 13.7 \\
\hline $30-39$ у.о. & 123 & 23.5 \\
\hline $40-49$ y.o & 169 & 32.3 \\
\hline $50-59$ y.o & 124 & 23.7 \\
\hline$>=60 \mathrm{y} .0$ & 36 & 6.9 \\
\hline \multicolumn{3}{|l|}{ Religion } \\
\hline Islam & 529 & 99.8 \\
\hline Christian & 1 & 0.2 \\
\hline \multicolumn{3}{|l|}{ Education } \\
\hline Elementary school & 167 & 31.7 \\
\hline Junior high school & 97 & 18.4 \\
\hline Senior high school & 192 & 36.4 \\
\hline Diploma/Academy & 13 & 2.5 \\
\hline S1 (undergraduate) & 57 & 10.8 \\
\hline S2/S3 (graduate) & 1 & 0.2 \\
\hline \multicolumn{3}{|l|}{ Type of business } \\
\hline Agriculture & 492 & 82.0 \\
\hline Fishery & 12 & 2.0 \\
\hline Livestock & 96 & 16.0 \\
\hline \multicolumn{3}{|l|}{ Farming experience } \\
\hline$>5$ years & 378 & 71.3 \\
\hline $1-5$ years & 119 & 22.4 \\
\hline$<1$ years & 18 & 0.03 \\
\hline
\end{tabular}

Table 3. Experience in borrowing fund from conventional/offline provider

\begin{tabular}{lcc}
\hline Category & $\mathrm{N}$ & $\%$ \\
\hline Experience using offline lending & & \\
Have experience & 178 & 34.4 \\
Have no experience & 340 & 65.6 \\
Lending provider & & \\
Conventional bank & 76 & 42.7 \\
Sharia bank & 1 & 0.6 \\
Cooperative & 6 & 3.4 \\
Others (moneylender/middleman) & 95 & 53.4 \\
Lending criteria & & \\
Low return obligation & 51 & \\
Low interest & 84 & \\
Not required to own land & 28 & \\
Simpler requirements & 168 \\
Bigger benefits & 49 & \\
Afford to pay & 77 \\
Profit sharing scheme & 98 \\
No interest (related to religion) & 30 \\
\hline
\end{tabular}

\section{Validity and Reliability Test}

Reliability test is aimed to measure the consistency level of research instruments. In this research the composite reliability is tested whether it is higher or equal with 0.70 . The reliability test of this research shows that all indicators are reliable. Whereas validity test is used to test the validity of the questionnaire. A questionnaire is valid if loading factor is $>0.50$. The result of validity test on all indicators in this questionnaire shows loading factor $>0.50$, meaning it has fulfilled the validity requirements, subsequently there is no elimination of variable. The reliability as well as validity test result can be seen in Table 4 .

\section{Goodness of Fit Test}

Goodness of fit test is aimed to see how well sample data fits the research model. This stage is related with the formation of initial model prior to estimation. The initial model is formulated based on a theory or previous studies. In Table 5 can be seen that RMSEA score is $0.07<0.08$ which means the model fits. Other criteria of goodness of model, which are CFI and NFI, result in score $>0.90$ which means the formulated model also fits. Therefore, it can be concluded that theoretical model fits the field condition based on the data sample

\section{Hypothesis Verification Results}

The structural model has been analyzed and the assessment of path coefficients showed that Performance Expectancy $(\mathrm{H} 1: \mathrm{b}=0.15$, t-value $=2.66)$, Hedonic Motivation $(\mathrm{H} 5: \mathrm{b}=0.23, \mathrm{t}$-value $=2.92)$, Price Value (H6: $b=0.18$, t-value $=2.33)$, Habit $(H 7$ : $\mathrm{b}=0.21, \mathrm{t}$-value $=2.73)$, and Values $(\mathrm{H} 8: \mathrm{b}=0.34$, $\mathrm{t}$-value $=5.14$ ) were found to be significant predictors of Behavioral Intention. Hypotheses verification can be seen in Table 6.

The acceptance of farmers towards P2P lending shows that performance expectation is one of the factors that is considered important for the farmers. This argument is reflected in hypothesis 1 (H1), which proposes that performance expectancy has positive effect on behavioral intention. The analysis result shows the there is significant correlation between performance expectancy and behavioral intention with t-value 2.66 (>1.96). 
Table 4. Reliability and validity test

\begin{tabular}{clcc}
\hline & Dimension & AVE & CR \\
\hline PE & Performance Expectancy & 0.50 & 0.85 \\
EE & Effort Expectancy & 0.60 & 0.86 \\
FC & Facilitating Conditions & 0.52 & 0.76 \\
SI & Social Influence & 0.68 & 0.90 \\
HM & Hedonic Motivation & 0.55 & 0.90 \\
PV & Price Value & 0.57 & 0.80 \\
H & Habit & 0.68 & 0.81 \\
V & Values & 0.64 & 0.84 \\
BI & Behavioral Intention & 0.65 & 0.88 \\
\hline
\end{tabular}

Table 5. Goodness of fit test

\begin{tabular}{lccc}
\hline Indicator & Score & Threshold & Conclusion \\
\hline $\begin{array}{l}\text { Chi-Square } \\
\text { (p-value) }\end{array}$ & 0.00 & $>0.05$ & $\begin{array}{c}\text { Model does } \\
\text { not fit }\end{array}$ \\
RMSEA & 0.07 & $<0.08$ & Good Fit \\
NFI & 0.97 & $>0.90$ & Good Fit \\
CFI & 0.98 & $>0.90$ & Good Fit \\
\hline
\end{tabular}

Table 6. Hypothesis verification

\begin{tabular}{lcccc}
\hline Correlation & $\begin{array}{c}\text { Path } \\
\text { Coefficient }\end{array}$ & $\begin{array}{c}\text { T- } \\
\text { value }\end{array}$ & $\begin{array}{c}\text { P- } \\
\text { value }\end{array}$ & $\begin{array}{c}\text { Sig- } \\
\text { nificance }\end{array}$ \\
\hline $\mathrm{H} 1: \mathrm{PE} \rightarrow \mathrm{Y} 1$ & 0.15 & 2.66 & 0.00 & $*$ \\
$\mathrm{H} 2 \mathrm{EE} \rightarrow \mathrm{Y} 1$ & -0.07 & -0.94 & 0.34 & \\
$\mathrm{H} 3: \mathrm{FC} \rightarrow \mathrm{Y} 1$ & -0.09 & -1.87 & 0.06 & \\
$\mathrm{H} 4 \mathrm{SI} \rightarrow \mathrm{Y} 1$ & 0.06 & 1.92 & 0.06 & \\
$\mathrm{H} 5 \mathrm{HM} \rightarrow \mathrm{Y} 1$ & 0.23 & 2.92 & 0.00 & $*$ \\
$\mathrm{H} 6: \mathrm{PV} \rightarrow \mathrm{Y} 1$ & 0.18 & 2.33 & 0.02 & $*$ \\
$\mathrm{H} 7 \mathrm{H} \rightarrow \mathrm{Y} 1$ & 0.21 & 2.73 & 0.00 & $*$ \\
$\mathrm{H} 8 \mathrm{~V} \rightarrow \mathrm{Y} 1$ & 0.34 & 5.14 & 0.00 & $*$ \\
\hline
\end{tabular}

*) identifies Path Coefficient score significant at error rate $5 \%$, which is absolute score of t-value $>1.96$

This finding is consistent with the study conducted by Yapp et al. (2018); Chen and Salmanian (2017); Tarhini et al. (2017). This result shows that farmers expect $\mathrm{P} 2 \mathrm{P}$ lending gives easiness in accessing funding for farming. This is understandable considering that currently getting access to financial sources is the main challenge facing the farmers.

The next analysis result shows that hypothesis 5 (H5), which proposes that hedonic motivation has positive effect on behavioral intention, is accepted with $\mathrm{t}$-value 2.92 (> 1.96). This result is aligned with most of previous studies which showed that hedonic motivation positively influences behavioral intention to adopt technology (Leong et al. 2017; Yapp et al. 2018;
Martins et al. 2018; Lin et al. 2017; Tak and Panwar 2017).

Hedonic motivation in this research is measured based on farmers' perception on the application and service of P2P lending which provides exciting experience and the easiness of access. This result shows that it is important for the farmers to enjoy using technology and create exciting experience, thus it will drive them to adopt.

Hypothesis 6 (H6) which proposes that price value has positive effect on behavioral intention to adopt $\mathrm{P} 2 \mathrm{P}$ is accepted. The t-value $2.33(>1.96)$ shows that there is significant correlation between price value and behavioral intention to adopt P2P lending. This means that the farmers are price sensitive. They need to ensure that the benefits they will obtain is more than the cost that they need to spend.

The previous research from Tak and Panwar (2017) argued that many people use online media as a habit. This is aligned with the analysis result of hypothesis 7 (H7) which shows that habit is a variable that effects significantly on behavioral intention to adopt P2P lending with $\mathrm{t}$-value $2.73(>1.96)$. This means that the repeat use will form a knowledge which eventually can drive farmers to participate in P2P lending.

Piscicelli et al. (2014) in previous research stated that in social psychology, values are understood as motivational construction in the individual and translated into behavior. In particular, values are often considered effecting consumer behavior and have a role in motivating behavior. Analysis result of hypothesis 8 (H8) shows that values has significant correlation with behavioral intention with t-value $5.14(>1.96)$. Values positively effect behavioral intention of farmers to adopt P2P lending. Referring to Schwartz basic values theory (2012), farmers are motivated to adopt P2P lending while considering tradition, achievement, benevolence and stimulation.

Tradition, including maintaining and preserving culture, family and religion, is considered by farmers as the motivation of behavioral intention to adopt P2P lending. Considering the majority religion of respondents is Islam, one of main criteria of lending expected by farmers is profit sharing scheme, which does not apply interest. Currently the farming funding P2P lending applies profit sharing scheme instead of interest scheme, which is in favor of farmers' expectation. 
Beside tradition, farmers also have a hope that $\mathrm{P} 2 \mathrm{P}$ lending can help them to achieve success in farming (achievement). Hence, with success that they achieve, they can do good to others (benevolence). Adopting P2P lending as an alternative of funding source is expected to improve the wealth of family, farmers and all parties involved.

In this research, effort expectancy does not show any significant correlation. This result is aligned with the study of Madan and Yadav (2016) on behavioral intention to adopt electronic transaction.

Facilitating conditions as well as social influence also do not show significant correlation with behavioral intention in this research. This is consistent with the research by Leong et al. (2017) which analyzed adoption behavior of IoT in Malaysia. This is possible because $\mathrm{P} 2 \mathrm{P}$ lending is a new concept for the farmers, hence the more detailed explanation about the P2P lending system and mechanism is needed.

\section{Managerial Implications}

$\mathrm{P} 2 \mathrm{P}$ lending is a new hope to address the constraints of smallholder farmers' accessibility to capital sources. In order to address the low adoption rate of P2P lending among farmers, an understanding of the driving factors of adoption is necessary.

The research result shows that performance expectancy, hedonic motivation, price value, habit and values have important role in driving farmers to participate in $\mathrm{P} 2 \mathrm{P}$ lending, thus farmers have a big hope that P2P lending can help them to achieve success and improve the wealth of their family and all parties involved in farming activities.

As the implications from practical point of view, subsequently the $\mathrm{P} 2 \mathrm{P}$ lending provider has to address these concerns by performing some initiatives, such as giving intensive education to the farmers about the benefits of participating in $\mathrm{P} 2 \mathrm{P}$ lending. The education will be more effective if performed by field agents who closely interact with the farmers on regular basis. Showing the farmers and giving them opportunity to experience directly of how to use P2P lending platform can create habit and familiarity of the farmers towards technology use which eventually can drive them to adopt. It will be beneficial also to show the success story of the farmers who have adopted farming funding P2P lending.
As for the theoretical implications, the outcome of this research is to develop a conceptual research framework which enables a better understanding of the factors that influence the farmers' behavioral intention to participate in farming funding $\mathrm{P} 2 \mathrm{P}$ lending in Indonesia. This research concludes that performance expectancy, hedonic motivation, price value, habit and values play significant roles in influencing farmers' behavioral intention to adopt farming funding P2P lending.

Another significant contribution of this study is to demonstrate that values, as a new variable in this research model, contribute significantly as one of the factors that drive farmers' behavioral intention to adopt farming funding P2P lending. The role of values had not been investigated before in technology acceptance research. The results of this research validate and confirm that values are important factor in the study of $\mathrm{P} 2 \mathrm{P}$ lending adoption.

\section{CONCLUSIONS AND RECOMMENDATIONS}

\section{Conclusions}

This study is performed based on the background in which the adoption rate of farming funding $\mathrm{P} 2 \mathrm{P}$ lending among smallholder farmers is relatively still low. In fact, the farming funding P2P lending provides them access to capital which they cannot get from formal banking institution due to requirements that cannot be fulfilled by smallholder farmers, such us collateral and land ownership. Farming funding P2P lending does not require the farmers to own land or asking for collaterals, which is an ease for the smallholder farmers. Farming funding P2P lending also offers other benefits for smallholder farmers, which are not provided by formal banking institution or informal lenders such as middleman or moneylender. One of other benefits offered by farming funding P2P lending providers is that they do not apply interest scheme, instead they apply profit sharing scheme which is in favor of smallholder farmers.

In order to improve the participation of the farmers it is important to understand the factors driving farmers to adopt P2P lending. UTAUT2 is adopted in this research considering $\mathrm{P} 2 \mathrm{P}$ lending uses technology in its implementation, i.e. internet connection. The result identified that performance expectancy, hedonic motivation, price value, habit and values have significant 
correlation with farmers' behavioral intention to adopt P2P lending.

\section{Recommendations}

The limitation of this research is the limited number of samples. Accordingly, it is recommended to expand the sample size as well as the geographic locations in order to obtain better generalization on farmers' behavioral intention to adopt farming funding P2P lending.

The limited variables used in this research is also a room to improve in future research. Including variable trust would substantially contribute to have a better understanding on farmers' behavioral intention to adopt farming funding P2P lending. Trust is a relevant variable in which might drive farmers to adopt farming funding P2P lending.

\section{ACKNOWLEDGEMENTS}

I gratefully acknowledge the supports from the farmers in Bandung, Sukabumi and Kuningan as well as the 11 enumerators who have made this research possible. I also would like to express gratitude to the founders of P2P lending providers who have given invaluable insights regarding farming funding $\mathrm{P} 2 \mathrm{P}$ lending.

\section{REFERENCES}

Alalwan AA, Dwivedi YK, Rana NPP, Williams MD. 2016. Consumer adoption of mobile banking in Jordan: Examining the role of usefulness, ease of use, perceived risk and self-efficacy. Journal of Enterprise Information Management 29(1): 118-139, https://doi.org/10.1108/JEIM-04-20150035

Al Imarah AA, Zwain A, Al-Hakim LAY. 2013. The adoption of e-government services in the Iraqi higher education context: an application of the UTAUT model in The University of Kufa. Journal of Information Engiuneering and Applications 3(10).

Anggraeni L. 2009. The Function of Social Networks for Informal Credits in Remote Rural Areas in Indonesia [Dissertation]. Tokyo: The University of Tokyo.

Ayyagari M., Demirguc-Kunt A., Maksimovic V. 2010. Formal versus Informal Finance: Evidence from
China. The Review of Financial Studies 23(8): 3048-3097. https://doi.org/10.1093/rfs/hhq030.

Banerjee S. 2016. A social marketing framework for innovation and technology adoption: the cadse of agricultural extension in India. Journal of Self- Governance and Management Economics 4(2):63-82.https://doi.org/10.22381/ JSME4220163.

Bentler PM, Chou CP. 1987. Practical issues in structural modelling. Sociological Methods \& Research 16(1): 78-117. https://doi.org/10.1177 /0049124187016001004.

Botsman R, Rogers R. 2010. What's Mine is Yours: How Collaborative Consumption is Changing the Way We Live. New York: HarperCollins Publishers.

BPS. 2013. Laporan Hasil Pertanian 2013. http:// st2013.bps.go.id/st2013esya/booklet/at0000.pdf

CaoM,ZhangQ,\&SeydelJ.2005.B2Ce-commerceweb site quality: an empirical examination. Industrial Management \& Data Systems 105(5): 645-61. https://doi.org/10.1108/02635570510600000.

Chen Y, Salmanian W. 2017. User acceptance in the sharing economy. An explanatory study of transportation network companies in China based on UTAUT2. Finland: Jonkoping University.

Davis FD. 1989. Perceived usefulness, perceived ease of use, and user acceptance of information technology. MIS Quarterly 13(3):319-340. https://doi.org/10.2307/249008.

Everett CR. 2010. Group membership, relationship banking and loan default risk : the case of online social lending group. West Lafayette, IN. http:// ssrn.com/abstract $=1114428$ [12/03/18]. https:// doi.org/10.2139/ssrn.1114428.

Fishbein M, Ajzen I. 1975. Belief, attitude, intention and Behavior: An introduction to theory and research. Addison-Wesley Publishing Company.

Hermawan H, Adrianyta H. 2013. Peran tambahan modal terhadap pendapatan usahatani padi. Jurnal Pengkajian dan Pengembangan Teknologi Pertanian 16(2): 132-39.

Herrero-Lopez S. 2009. Social interactions in P2P lending. Proceedings of the 3rd Workshop on Social Network Mining and Analysis (pp. 1-8). Paris: ACM. http://portal.acm.org/citation. cfm?id=1731011.1731014 [12/03/18]. https:// doi.org/10.1145/1731011.1731014.

Indiastuti R. 2005. Arti Tahun Keuangan Mikro bagi Indonesia. http:www.pikiran-rakyat.com/ cetak/2005/0305/08/0608.htm[12/03/18]. 
Indonesian Financial Service Authority [OJK]. 2016. Regulation on information technology-based lending or Fintech. Retrieved on 11 December 2019 from https://www.ojk.go.id/id/Regulasi/ Default.aspx

Johnston D, Murdoch J. 2008. The Unbanked: Evidence from Indonesia. The World Bank Economic Review 22(3): 517-537. https://doi.org/10.1093/ wber/lhn016.

Khalifa M, Kathy SN. 2008. Drivers for transactional b2c m-commerce adoption: extended theory of planned behavior. Journal of Computer Information Systems

Kim C, Lee I, Wang T, Mirusmonov, M. 2015. Evaluating effects of mobile crm on employees' performance. Industrial Management \& Data Systems 115 (4): 740-764. https://doi. org/10.1108/IMDS-08-2014-0245.

Koufaris M, Hampton-Sosa W. 2004. The development of initial trust in an online company by new customers. Information Management 41(3):377397. https://doi.org/10.1016/j.im.2003.08.004.

Leong GW, Ping TA, Muthuveloo R. 2017. Antecedents of behavioral intention to adopt internet of things in the context of smart city in Malaysia. Global Business and Management Research: An International Journal 9(4s): 442-56.

Lin H, Wang M, Wu MJ. 2017. A study of Airbnb use behavior in the sharing economy. International Journal of Organizational Innovation 10(1): 38-47.

Madan K, Yadav R. 2016. Behavioural intention to adopt mobile wallet: a developing country perspective. Journal of Indian Business Research 8(3):227-244. https://doi.org/10.1108/JIBR-102015-0112.

Mardhiyyah YS, Rasyidi MA, Hidayah L. 2020. Factors affecting crowdfunding investor number in agricultural projects: the dummy regression model. Jurnal Manajemen \& Agribisnis 17(1): 14-24.https://doi.org/10.17358/jma.17.1.14.

Martins M, Farias JS, Albuquerque, PHM, Pereira DS. 2018. Adoption of technology for reading purposes: a study articles of e-books acceptance. Brazilian Business Review 15(6): 568-88. https:// doi.org/10.15728/bbr.2018.15.6.4.

Megasari L. 2017. Ketergantungan petani terhadap tengkulak sebagai patron dalam kegiatan proses produksi pertanian (studi di Desa Baye Kecamatan Kayen Kidul Kabupaten Kediri). http://repository.unair.ac.id/87566/5/
JURNAL LUTFI\%20APRELIANA\%20 MEGASARI_071511433032.PDF.pdf [10 Jun 2019].

Mulyaqin T, Astuti Y, Haryani D. 2016. Faktor yang mempengaruhi petani padi dalam pemanfaatan sumber permodalan: studi kasus di Kabupaten Serang Provinsi Banten. Conference Seminar Nasional BPTP Jambi 2(1)

Nurmanaf AR. 2007. Lembaga informal pembiayaan mikro lebih dekat dengan petani. Analisis Kebijakan Pertanian 5(2): 99-109.

Pattern RH, Rosengard JK. 1991. Progress with Profits: The Development of Rural Banking in Indonesia [Working Paper]. San Francisco: International Center for Economic Growth.

Piscicelli L, Cooper T, \& Fisher T. 2014. The role of values in collaborative consumption: insights from a product-service system fr lending and borrowing in the UK. Journal of Cleaner Production (2014): 1-9.

PratiwiDE, Ambayoen MA, \& HardanaAE. 2019. Studi pembiayaan mikro petani dalam pengambilan keputusan untuk kredit formal dan kredit nonformal. HABITAT, 30(1): 35-43. https://doi. org/10.21776/ub.habitat.2019.030.1.5

Schwartz SH. 2012. An overview of the Schwartz theory of basic values. Psychology and Culture Article 11:12-13. https://doi.org/10.9707/23070919.1116.

Tak P, Panwar S. 2017. Using UTAUT 2 model to predict mobile app-based shopping: evidences from India. Journal of Indian Business Research 9(3): 248-64. https://doi.org/10.1108/JIBR-112016-0132.

Tarhini A, Masa'deh R, \& Al-Busaidi KA. 2017. Factors influencing students' adoption of e-learning: a structural equation modeling approach. Journal of International Education in Business 10(2): 164-82. https://doi.org/10.1108/JIEB-09-20160032.

Van der Heijden $H$, Verhagen $T$, \& Creemers $M$. 2003. Understanding online purchase intentions: contributions from technology and trust perspectives. European Journal of Information Systems 12:. 41-8. https://doi.org/10.1057/ palgrave.ejis.3000445.

Venkatesh V, Thong JYL, Xu X. 2012. Consumer acceptance and use of information technology: extending the unified theory of acceptance and use of technology. MIS Quarterly 36(1): 157178. https://doi.org/10.2307/41410412. 
Yapp EH, Balakrishna C, Yeap JAL, \& Ganesan Y. 2018. Male and female technology users' acceptance of on-demand services. Global Business and Management Research: An International Journal 10(2018, Special Issue).
Wineka P. 2019. E-Commerce and P2P lending Tanihub received series A funding USD 10 million. https://teknologi.bisnis.com/ $\mathrm{read} / 20190610 / 266 / 932132 / \mathrm{e}-c o m m e r c e-d a n-$ p2p-lending-tanihub-raih-pendanaan-seri-aus10-juta [10 Jun 2019]. 